\title{
ANALISIS KUALITAS PRODUK \\ DALAM PENGEMBANGAN BISNIS NUGGET JAMUR TIRAM PUTIH ANEKA RASA BUMBU MASAKAN TRADISIONAL
}

\author{
Dina Rahayu ${ }^{1}$, Agus Sudono ${ }^{2}$, Eeng Ahman ${ }^{3}$ \\ PROGRAM STUDI MANAJEMEN INDUSTRI KATERING, FPIPS \\ UNIVERSITAS PENDIDIKAN INDONESIA
}

J1. Dr. Setiabudi no. 229 Bandung Kode Pos: 40154 Telp/ Fax: 022- 2007140

e-mail: d.sereal@gmail.com

\begin{abstract}
Research Method used Randomized Block Design \& Friedman test was used as organoleptic test. Break Event Point (BEP), Payback Period (PP), Net Present Value (NPV) and Profitability Index (PI) were used in calculating financial Anlysis.

The result of researched, showed the best treatment based on effectivity index which obtained from $100 \mathrm{~g}$ Pleurotus ostreatus, taste 6.14; colour 5,67; flavour 6,47; shape 6, 20 dan texture 6,33 .Cost of Production (HPP) Rp. 6412.77 / $200 g$ r retrieval assuming a 50\% mark up to Rp. 9700, - / $200 \mathrm{~g}$. BEP calculations on sales volume reached 26231.64 units or Rp. 252,326,195.59. Payback Period is achieved in 3 years 3 months 27 days. Value Net Present Value (NPV) of Rp. 118,894,282.67, -. Profitability Index (PI) 1, 33, nugget production business unit of the white oyster mushroom flavors of traditional cuisine is feasible.
\end{abstract}

Key words: Mushroom Nugget Traditional Recipe, Business Development

\section{ABSTRAK}

Metode penelitian ini menggunakan Rancangan Acak Tunggal (RAT), uji organoleptik menggunakan Uji Friedman dan penentuan perlakuan terbaik organoleptik menggunakan index efektifitas. Analisis kelayakan finansial menggunakan perhitungan Break Event Point (BEP), Payback Period (PP), Net Present Value (NPV) dan Profitability Index (PI).

Hasil penelitian menyajikan perlakuan terbaik berdasarkan index efektifitas diperoleh dari jamur tiram putih $100 \mathrm{~g}$, dengan lima parameter uji organoleptik rasa 6,14; warna 5,67; aroma 6,47; bentuk 6, 20 dan tekstur 6,33. Hasil kajian Kelayakan finansial produksi nugget jamur tiram putih bumbu masakan tradisional didapatkan Harga Pokok Produksi (HPP) sebesar Rp. 6.412,77/ 200gr dengan asumsi pengambilan mark up sebesar 50\% Rp. 9.700,-/ 200 g. Perhitungan BEP dicapai pada volume penjualan 26.231,64 unit atau senilai Rp. 252.326.195,59. Payback Period dicapai pada 3 tahun 3 bulan 27 hari. Nilai Net Present Value (NPV) sebesar Rp. 118.894.282,67,-. Profitability Index (PI) sebesar 1, 33 dengan demikian unit usaha produksi nugget dari jamur tiram putih aneka rasa masakan tradisional layak dilaksanakan.

Kata kunci: Nugget Jamur Tiram Putih Bumbu Tradisional, Pengembangan Bisnis 


\section{PENDAHULUAN}

\section{Latar Belakang}

Salah satu makanan beku yang sudah cukup dikenal di Indonesia dan disukai oleh hampir semua orang adalah nugget, karena rasanya enak, penyimpanan dan penyajiannya yang praktis. Nugget jamur (mushroom nugget) merupakan salah satu makanan baru, dibuat dari jamur tiram putih dengan penambahan bumbu tradisional Indonesia, kemudian dicetak, dilumuri dengan pelapis yang dilanjutkan dengan penggorengan. Pada dasarnya nugget jamur sama dengan nugget ayam atau nugget ikan, perbedaannya terletak pada bahan baku yang digunakan.

Jamur merupakan bahan pangan yang mulai banyak diminati oleh masyarakat, disamping harganya yang murah juga kandungan gizinya tinggi. Beberapa jenis jamur yang telah dibudidayakan dan memiliki nilai bisnis besar diantaranya adalah jamur merang, jamur kuping, shitake, champingnon, lingzi dan jamur tiram (Sumarmi, 2006).

Saat ini jamur tiram putih adalah jamur komersial yang diproduksi terbesar ke tiga di dunia (Obodai et al., 2003:146).

Jamur tiram putih adalah salah satu jamur yang sangat enak dimakan serta mempunyai kandungan protein yang cukup tinggi dibandingkan dengan jamur lain, seperti pada jamur tiram putih mengandung protein $27 \%$, jamur merang mengandung protein $1,0 \%$ dan jamur champingnon mengandung protein 3,5\% dihitung dalam 100 gram berat kering oleh karena itu jamur tiram mulai dibudidayakan (Anonymous, 2009).

Bandung merupakan salah satu sentra produksi jamur tiram putih di Indonesia, terutama di daerah Ciwidey, Cisarua, Lembang dan Pengalengan (Puspita, 2011). Kabupaten Bandung mempunyai suhu rata-rata $21^{\circ} \mathrm{C}$ (Anonymous, 2012), sehingga sangat cocok untuk dilakukan budidaya jamur tiram putih. Saat ini kebutuhan konsumsi jamur di dunia juga terus meningkat sebanding dengan pertumbuhan jumlah penduduk dan pendapatan serta perubahan pola konsumsi makanan penduduk dunia, karena masyarakat semakin menyadari bahwa jamur bukan hanya sebagai makanan biasa tetapi mempunyai banyak keuntungan untuk kesehatan. Bandung yang merupakan sentra produksi jamur tiram putih di Jawa Barat dapat menghasilkan sekitar 10 ton per hari (Puspita, 2011).

Produk nugget jamur saat ini juga sudah mulai dipasarkan, tapi untuk dapat terus diterima dimasyarakat harus dilakukan inovasi produk nugget jamur dengan rasa yang lebih diterima oleh lidah orang Indonesia. Salah satunya dengan menggunakan rasa masakan tradisional khas Indonesia. Bumbu masakan tradisional Indonesia kaya akan rempah-rempah, yang meningkatkan aroma dan cita rasa makanan yang lezat (Rahayu, 2011). Selain rasanya yang enak, pemakaian bumbu masakan tradisional khas Indonesia pada nugget jamur juga sebagai salah satu bentuk media promosi budaya dan penghargaan kepada para pewaris bangsa agar hasil karya seninya tetap dilestarikan.

Pada makanan siap saji atau makanan yang beredar dipasaran, penggunaan bumbu masakan tradisional khas Indonesia masih jarang sekali, karena biasanya rasa yang digunakan pada makanan siap saji adalah rasa masakan Internasional. Pada makanan siap saji saat ini yang menggunakan bumbu masakan tradisional khas 
Indonesia baru ditemukan pada produk-produk mie instan. Bumbu masakan tradisional khas Indonesia yang sering digunakan untuk masakan diantaranya bumbu rendang, bumbu soto, bumbu gulai dan bumbu semur.

\section{METODE PENELITIAN}

Jenis penelitian pada penelitian ini yaitu penelitian deskriptif eksperimental.

Menurut Mohammad Nazir (2003:54), "tujuan dari penelitian deskripsi adalah membuat deskripsi, gambaran atau lukisan secara sistematis, faktual dan akurat, mengenai fakta-fakta, sifat-sifat, serta hubungan antar fenomena yang diselidiki”.

Sedangkan penelitian eksperimental menurut Suharsimi Arikunto (2005:207) adalah penelitian yang dimaksudkan untuk mengetahui ada tidaknya hubungan sebab akibat dari 'suatu' yang dikenakan pada subjek yang selidik. Dengan kata lain penelitian eksperimen mencoba meneliti ada tidaknya hubungan sebab akibat. Caranya adalah dengan membandingkan satu atau lebih kelompok yang tidak menerima perlakuan. Penelitian ini dilakukan dengan menggunakan pendekatan "Penelitian Pengembangan" (Research and Development).

\section{Operasionalisasi Variabel}

Variabel adalah objek penelitian, atau apa yang menjadi titik perhatian suatu penelitian". Arikunto(2002:96)

Variabel-variabel penelitian berisi dimensi-dimensi yang bersifat teoritis dan belum mampu untuk diukur, oleh karena itu peneliti perlu mengoperasionalisasikan variabel tersebut. Menurut Singarimbun dan Sofian Effendi (1989:46) "definisi operasional adalah unsur penelitian yang memberitahukan bagaimana caranya mengukur suatu variabel".

Ada pun variabel yang akan dikaji dalam penelitian ini adalah nugget jamur tiram putih $(\mathrm{X})$ sebagai variabel bebas (independent) dan rasa (original, rendang, soto, gulai, dan semur) sebagai variabel terikat bebas (dependent).

\section{Populasi, Sampel, dan Teknik Penarikan Sampel}

Suharsimi Arikunto (2002:108) mengemukakan bahwa "populasi adalah keseluruhan subjek penelitian. Apabila seseorang ingin meneliti semua elemen yang ada dalam wilayah penelitian, maka penelitiannya merupakan penelitian populasi."

Dalam penelitian ini khususnya uji organoleptik, populasi yang akan diambil adalah populasi sebanyak 15 orang panelis. maka peneliti mengambil seluruh populasi yang ada. Hal ini dikarenakan jumlah populasi kurang dari 100 orang.

Menurut Suharsimi Arikunto (2002:112) “apabila subjeknya kurang dari 100 lebih baik diambil semua sehingga penelitiannya merupakan penelitian populasi." Jadi dalam penelitian ini tidak ada sampel atau pun teknik penarikan sampel yang digunakan.

\section{Rancangan Percobaan}

Dalam percobaan ini digunakan Rancangan Acak Tunggal (RAT). Terdiri dari satu faktor, dimana faktor pertama terdiri dari satu level, dan faktor kedua terdiri dari empat level. Masing-masing level diulang sebanyak tiga kali. 
- Faktor 1: Bahan baku utama

$\mathrm{A}_{1} \quad$ : Nugget Jamur Tiram Putih

- Faktor 2 : Penambahan Flavour

$$
\begin{array}{ll}
\mathrm{B}_{1} & \text { : Rendang } \\
\mathrm{B}_{2} & \text { : Soto } \\
\mathrm{B}_{3} & \text { : Gulai } \\
\mathrm{B}_{4} & \text { : Semur }
\end{array}
$$

Dari kedua faktor tersebut didapat 4 kombinasi perlakuan

$\mathrm{A}_{1} \mathrm{~B}_{1} \quad$ : Nugget jamur tiram putih rasa rendang

$\mathrm{A}_{1} \mathrm{~B}_{2} \quad$ : Nugget jamur tiram putih rasa soto

$\mathrm{A}_{1} \mathrm{~B}_{3}$ : Nugget jamur tiram putih rasa gulai

$\mathrm{A}_{1} \mathrm{~B}_{4}$ : Nugget jamur tiram putih rasa semur

\section{Teknik Analisis Data}

Data hasil organoleptik dianalisis dengan metode statistik non parametrik menggunakan Uji Friedman dengan $(\boldsymbol{\alpha}=\boldsymbol{0 , 0 1})$. Perlakuan terbaik dilakukan dengan menggunakan metode indeks efektifitas (Susrini, 2005).

\section{HASIL PENELITIAN DAN PEMBAHASAN}

Pembuatan Nugget Jamur Tiram Putih Aneka Rasa Bumbu Masakan Tradisional

Penelitian tahap ini dilakukan untuk mengetahui kombinasi perlakuan terbaik berdasarkan uji organoleptik (rasa, warna, aroma, bentuk, dan tekstur). Parameter perbandingan menggunakan uji organoleptik (rasa, warna, aroma, bentuk, dan tekstur) dengan 15 panelis.

\section{Uji Organoleptik}

\section{Rasa}

Hasil analisis uji friedman $(\alpha=0,01)$ menunjukkan bahwa uji perbandingan pada berbagai kombinasi perlakuan memberikan pengaruh nyata pada uji organoleptik menunjukkan bahwa rata-rata ranking kesukaan panelis terhadap rasa dari kombinasi perlakuan antara jamur tiram putih yang ditambahkan dengan 4 bumbu tradisional Indonesia (rendang, soto, gulai, dan semur) berkisar antara 5 6,47. Semakin tinggi rata-rata ranking kesukaan panelis, maka tingkat kesukaan panelis terhadap rasa semakin besar.

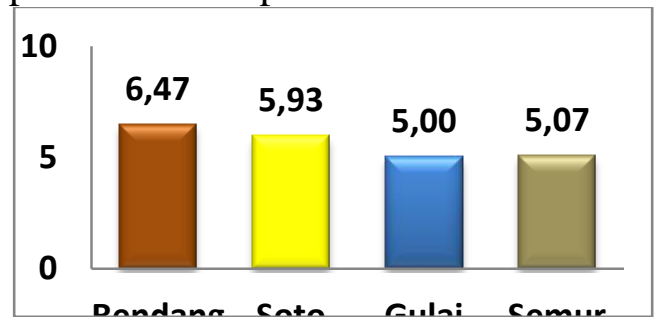

Gambar 1 Rata-rata Kesukaan Panelis terhadap Rasa 
Nilai terendah rata-rata kesukaan panelis terhadap rasa didapatkan sebesar 5,0 dari kombinasi perlakuan nugget jamur tiram dengan rasa gulai. Sedangkan nilai tertinggi sebesar 6,47 didapatkan dari kombinasi perlakuan nugget jamur tiram dengan rasa rendang.

\section{Warna}

Hasil uji organoleptik menunjukkan bahwa rata-rata ranking kesukaan panelis terhadap warna dari kombinasi perlakuan antara jamur tiram putih yang ditambahkan dengan 4 bumbu tradisional Indonesia (rendang, soto, gulai, dan semur) berkisar antara 4,6 - 5,67. Semakin tinggi rata-rata ranking kesukaan panelis, maka tingkat kesukaan panelis terhadap warna semakin besar.

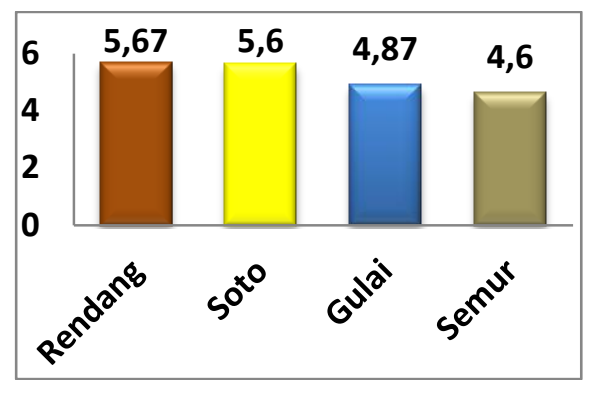

\section{Gambar 2 Rata-rata Kesukaan Panelis terhadap Warna}

Nilai terendah rata-rata kesukaan panelis terhadap warna didapatkan sebesar 4,6 dari kombinasi perlakuan nugget jamur tiram dengan rasa semur. Sedangkan nilai tertinggi sebesar 5,67 didapatkan dari kombinasi perlakuan nugget jamur tiram dengan rasa rendang.

\section{Aroma}

Hasil uji organoleptik menunjukkan bahwa rata-rata ranking kesukaan panelis terhadap aroma dari kombinasi perlakuan antara jamur tiram putih yang ditambahkan dengan 4 bumbu tradisional Indonesia (rendang, soto, gulai, dan semur) berkisar antara 4,93 - 6,47. Semakin tinggi rata-rata ranking kesukaan panelis, maka tingkat kesukaan panelis terhadap aroma semakin besar.

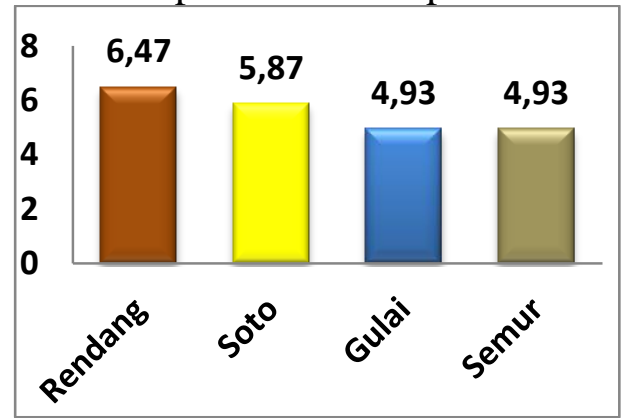




\section{Gambar 3 Rata-rata Kesukaan Panelis terhadap Aroma}

Nilai terendah rerata kesukaan panelis terhadap aroma didapatkan sebesar 4,93 dari kombinasi perlakuan nugget jamur tiram dengan rasa gulai dan semur. Sedangkan nilai tertinggi sebesar 6,47 didapatkan dari kombinasi perlakuan nugget jamur tiram dengan rasa rendang.

\section{Bentuk}

Hasil uji organoleptik menunjukkan bahwa rata-rata ranking kesukaan panelis terhadap bentuk dari kombinasi perlakuan antara jamur tiram putih yang ditambahkan dengan 4 bumbu tradisional Indonesia (rendang, soto, gulai, dan semur) berkisar antara 4,6 - 6,2. Semakin tinggi rata-rata ranking kesukaan panelis, maka tingkat kesukaan panelis terhadap bentuk semakin besar.

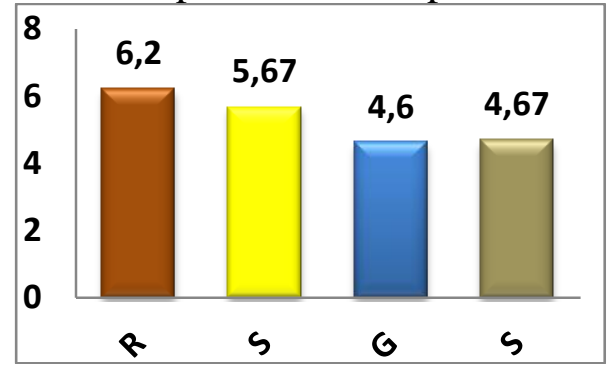

\section{Gambar 4 Rata-rata Kesukaan Panelis terhadap Bentuk}

Nilai terendah rerata kesukaan panelis terhadap bentuk didapatkan sebesar 4,6 dari kombinasi perlakuan nugget jamur tiram dengan rasa gulai. Sedangkan nilai tertinggi sebesar 6,2 didapatkan dari kombinasi perlakuan nugget jamur tiram dengan rasa rendang.

\section{Tekstur}

Hasil uji organoleptik menunjukkan bahwa rata-rata ranking kesukaan panelis terhadap tekstur dari kombinasi perlakuan antara jamur tiram putih yang ditambahkan dengan 4 bumbu tradisional Indonesia (rendang, soto, gulai, dan semur) berkisar antara 5,07 - 6,33). Semakin tinggi rerata ranking kesukaan panelis, maka tingkat kesukaan panelis terhadap tekstur semakin besar.

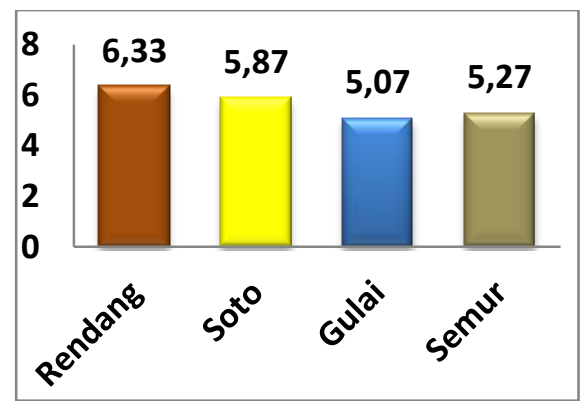

Gambar 5 Rata-rata Kesukaan Panelis terhadap Tekstur

Nilai terendah rerata kesukaan panelis terhadap tekstur didapatkan sebesar 5,07 dari kombinasi perlakuan nugget jamur tiram dengan rasa gulai. Sedangkan 
nilai tertinggi sebesar 6,33 didapatkan dari kombinasi perlakuan nugget jamur tiram dengan rasa rendang.

Kelayakan Finansial Produksi Nugget Jamur Tiram Putih Rasa Rendang Break Event Point (BEP)

Hasil perhitungan BEP menunjukkan bahwa titik balik pokok akan dicapai pada volume penjualan 26.231,64 unit atau senilai Rp. 252.326.195,59. Apabila perusahaan telah mencapai angka penjualan tersebut di atas, maka dapat diartikan bahwa perusahaan telah mencapai titik dimana perusahaan tidak mengalami kerugian maupun memperoleh keuntungan.

Payback Period (PP)

Payback Period merupakan metode yang digunakan untuk mengukur kecepatan pengembalian modal investasi yang dinyatakan dalam tahun. Hasil perhitungan menunjukkan bahwa nilai payback period dicapai pada 3 tahun 3 bulan 17 hari. Hal ini menunjukkan bahwa dalam jangka waktu tersebut nilai investasi usaha sebesar Rp. 359.210.500,- telah kembali. Lama payback period lebih pendek daripada umur proyek yang direncanakan yaitu selama 5 tahun, sehingga dapat dikatakan proyek ini layak untuk dilaksanakan.

Profitability Index (PI)

Nilai Profitability Index (PI) bernilai positif atau lebih besar dari nol, yaitu sebesar 1,33. Menurut Husnan dan Suwarsono (2002), proyek dinyatakan layak, apabila PI $>0$. Sedangkan unit usaha pengolahan nugget dari jamur tiram putih ini, mempunyai PI > 0, maka pengolahan ini layak dilaksanakan.

\section{Perbandingan Uji Organoleptik Dengan Produk Chicken Nugget di Pasaran}

Pada tahap ini, kombinasi perlakuan terbaik akan dilakukan perbandingan uji organoleptik dengan produk nugget yang ada di pasaran chicken nugget merk So Good, Champ, dan Fiesta.

Perhitungan perbandingan produk nugget menggunakan Analisis Varian (ANAVA) dengan BNT $1 \%$.

\section{Uji Organoleptik}

Rasa

Hasil uji organoleptik menunjukkan bahwa rerata ranking kesukaan panelis terhadap rasa antara D'jamur dengan produk chicken nugget di pasaran berkisar antara 5,5-6,7.

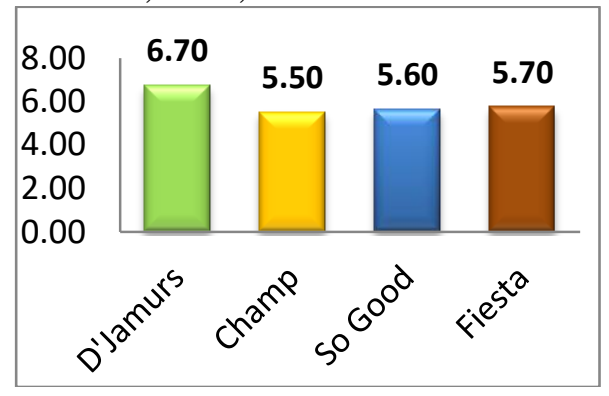




\section{Gambar 6 Rerata Kesukaan Panelis terhadap Rasa}

Nilai terendah rerata kesukaan panelis terhadap rasa didapatkan sebesar 5,5 dari produk chicken nugget merk champ. Sedangkan nilai tertinggi sebesar 6,70 didapatkan dari produk nugget merk D'Jamurs.

Hasil analisis Uji BNT $(\alpha=0,01)$ menunjukkan bahwa uji perbandingan pada berbagai perlakuan memberikan pengaruh nyata terhadap rerata kesukaan rasa pada berbagai produk chicken nugget di pasaran. Perlakuan terbaik tingkat kesukaan rasa diperoleh dari produk nugget merk D'Jamurs.

\section{Warna}

Hasil uji organoleptik menunjukkan bahwa rerata ranking kesukaan panelis terhadap warna antara D'Jamurs dengan produk chicken nugget di pasaran berkisar antara $5,1-6,5$.

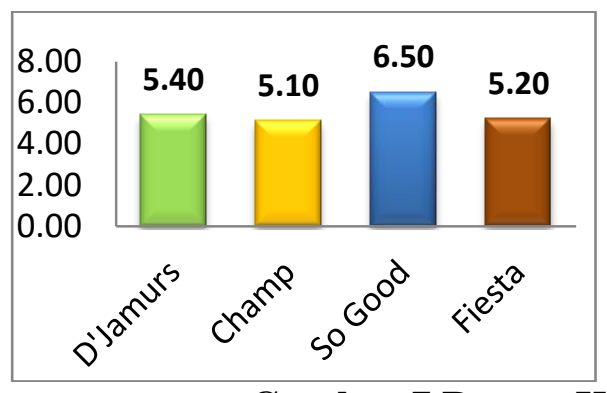

\section{Gambar 7 Rerata Kesukaan Panelis terhadap Warna}

Nilai terendah rerata kesukaan panelis terhadap warna didapatkan sebesar 5,1 dari produk chicken nugget merk champ. Sedangkan nilai tertinggi sebesar 6,70 didapatkan dari produk chicken nugget merk So Good. Hasil analisis Uji BNT $(\alpha=$ 0,01) menunjukkan bahwa uji perbandingan pada berbagai perlakuan memberikan pengaruh nyata terhadap rerata kesukaan warna pada berbagai produk chicken nugget di pasaran. Perlakuan terbaik tingkat kesukaan warna diperoleh dari produk chicken nugget merk So Good. Aroma

Hasil uji organoleptik menunjukkan bahwa rerata ranking kesukaan panelis terhadap aroma antara D'jamurs dengan produk chicken nugget di pasaran berkisar antara $5-6,2$.

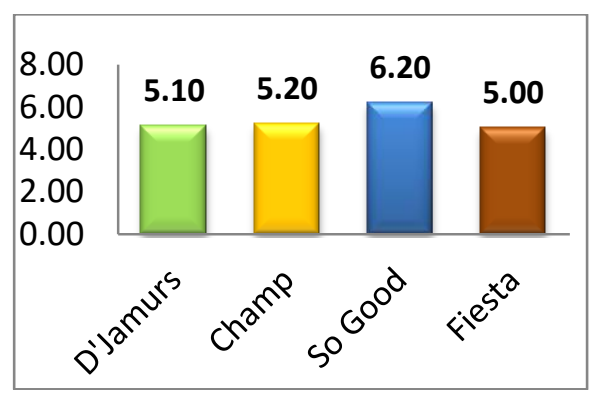




\section{Gambar 8 Rerata Kesukaan Panelis terhadap Aroma}

Nilai terendah rerata kesukaan panelis terhadap aroma didapatkan sebesar 5,0 dari produk chicken nugget merk fiesta. Sedangkan nilai tertinggi sebesar 6,20 didapatkan dari produk chicken nugget merk So Good.

Hasil analisis Uji BNT $(\alpha=0,01)$ menunjukkan bahwa uji perbandingan pada berbagai perlakuan memberikan pengaruh nyata terhadap rerata kesukaan aroma pada berbagai produk chicken nugget di pasaran. Perlakuan terbaik tingkat kesukaan aroma diperoleh dari produk chicken nugget merk So Good.

\section{Bentuk}

Hasil uji organoleptik menunjukkan bahwa rerata ranking kesukaan panelis terhadap bentuk antara D'jamurs dengan produk chicken nugget di pasaran berkisar antara 4,9-6,3.

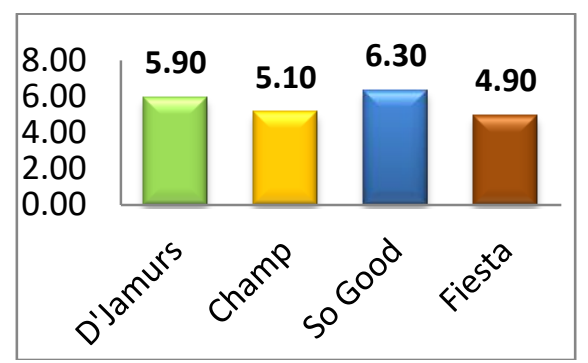

\section{Gambar 9 Rerata Kesukaan Panelis terhadap Bentuk}

Nilai terendah rerata kesukaan panelis terhadap bentuk didapatkan sebesar 4,9 dari produk chicken nugget merk fiesta. Sedangkan nilai tertinggi sebesar 6,30 didapatkan dari produk chicken nugget merk So Good.

Hasil analisis Uji BNT $(\alpha=0,01)$ menunjukkan bahwa uji perbandingan pada berbagai perlakuan memberikan pengaruh nyata terhadap rerata kesukaan bentuk pada berbagai produk chicken nugget di pasaran. Perlakuan terbaik tingkat kesukaan bentuk diperoleh dari produk chicken nugget merk So Good.

\section{Tekstur}

Hasil uji organoleptik menunjukkan bahwa rerata ranking kesukaan panelis terhadap tekstur antara D'jamurs dengan produk chicken nugget di pasaran berkisar antara 5,2-6,8.

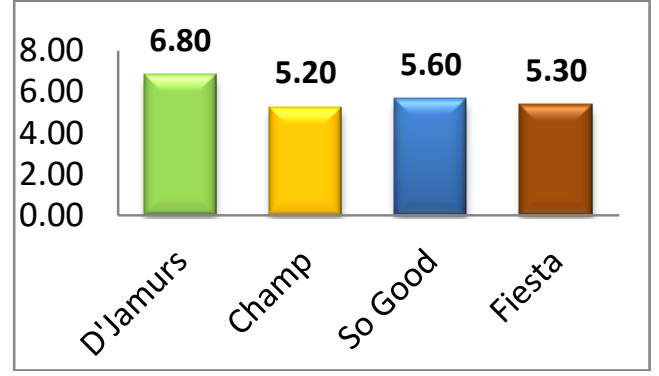




\section{Gambar 10 Rerata Kesukaan Panelis terhadap Tekstur}

Nilai terendah rerata kesukaan panelis terhadap tekstur didapatkan sebesar 5,2 dari produk chicken nugget merk champ. Sedangkan nilai tertinggi sebesar 6,80 didapatkan dari produk nugget merk D'Jamurs.

Hasil analisis Uji BNT $(\alpha=0,01)$ menunjukkan bahwa uji perbandingan pada berbagai perlakuan memberikan pengaruh nyata terhadap rerata kesukaan tekstur pada berbagai produk chicken nugget di pasaran. Perlakuan terbaik tingkat kesukaan tekstur diperoleh dari produk nugget merk D'Jamurs..

\section{KESIMPULAN}

\section{Kesimpulan}

Berdasarkan hasil analisis data dan pembahasan yang telah dilakukan terhadap penelitian Nugget Jamur Tiram Putih Aneka Rasa untuk mengetahui kualitas produk dan layak atau tidaknya bisnis ini dijalankan, maka dapat diambil beberapa kesimpulan sebagai berikut.

1. Secara umum kualitas produk nugget jamur tiram putih aneka rasa masakan tradisional dianggap sudah layak konsumsi secara kualitas oleh panelis selaku responden penelitian. Hal tersebut terlihat dari mayoritas jawaban penilaian panelis dalam kategori pemberian skor tertinggi pada perlakuan A1B1 rasa rendang.

2. Secara umum gambaran produk nugget jamur tiram putih aneka rasa bumbu msakan tradisional dilihat dari unsur parameter penilaian produk nugget yang memiliki skor tertinggi terletak pada perlakuan A1B1 adalah rasa rendang dengan penentuan penilaian lima parameter rasa, warna, aroma, bentuk dan tekstur.

3. Berdasarkan kelayakan finansial produk nugget jamur tiram putih rasa rendang didapatkan:

a. Harga Pokok Produksi (HPP) sebesar Rp. 6.412,77 dengan asumsi pengambilan mark up sebesar 50\% Rp. 9.700,-/ $200 \mathrm{~g}$ dari setiap produk unit yang terjual .

b. Break Even Point (BEP) dicapai pada volume penjualan 26.231,64 unit atau senilai Rp. 252.326.195,59.

c. Payback Period dicapai pada 3 tahun 3 bulan 27 hari.

d. Net Present Value Rp 118.894.282,67

e. Profitability Index (PI) yaitu sebesar 1,33

Dengan demikian unit usaha produksi nugget dari jamur tiram putih dengan aneka rasa layak dilaksanakan.

\section{DAFTAR PUSTAKA}

Arikunto, Suharsimi. (2010). Prosedur Penelitian, Suatu Pendekatan Praktek. Jakarta: PT. Rineka Cipta

Bobek, P., Ozdin, L. dan Galbavy, S. (1998). Dose- and time-dependent hypercholesterolaemic effect of oyster mushroom (Pleurotus ostreatus) in 
rats. Nutrition 14, 282-286. Tersedia : http://www.springerlink.com/. (20 februari 2012).

Francis, F.J. (2000). "Starch" dalam Willey Encyclopedia of Food Science and Technology. John Willey and Sons, Inc. New York. 2203-2209. Tersedia : http://www.google.co.id/. (20 Februari 2012)

Gunawan, S. (2004). Statistik. Penerbit Andi. Yogyakarta

Hossain, S., Hashimoto, M., Choudhury, E., Alam, N., Hussain, S., Hasan, M., Choudhury, S. dan Mahmud, I. (2003). Dietary mushroom (Pleurotus ostreatus) ameliorates at Clinical and Experimental 40 lipid in hypercholesterolaemic rats. http://www.springerlink.com/. (20 Februari 2012)

Husnan \& Suwarsono.(2002) Studi Kelayakan Proyek . AMP YKPN. Yogyakarta.

Puspita, R. (2011). Perencanaan Bisnis Jamur. Karya Ilmiah STMIK AMIKOM, Yogyakarta. Tersedia : http://www.google.co.id/. (20 Februari 2012)

Rahmana, A. (2009). Peranan Teknologi Informasi Dalam Peningkatan Daya Saing Usaha Kecil Menengah. Seminar Nasional Aplikasi Teknologi Informasi 2009 (SNATI 2009) Yogyakarta, 20 Juni 200. ISSN: 1907-5022. Tersedia : http://www.google.co.id/. (22 Februari 2012)

Rahayu, W.P. (1998). Penuntun Praktikum Penilaian Organoleptik. Jurusan Teknologi Pangan, Fakultas Teknologi Pertanian, Institut Pertanian Bogor. Bogor.

Sumarmi. (2006). Botani Dan Tinjauan Gizi Jamur Tiram Putih. Jurnal Inovasi Pertanian Vol. 4, No. 2. Tersedia: http://www.google.co.id/. (20 Februari 2012)

Sugiyono. (2011). Metode Penelitian Kuantitatif Kualitatif dan R\&D. Bandung: Alfabeta

Suzuki, T. (1981). Fish Krill Protein Procesing Technology. Aplied Science Publisher, Ltd. London. http://www.google.co.id/. Diakses tanggal 30 Oktober 2009

Umar, H. (2003). Studi Kelayakan Dalam Bisnis Jasa: Manajemen, Metode, dan Kasus. Penerbit PT Gramedia Pustaka Utama, Jakarta.

Wibowo,S.,(2002).Pedoman Mengelola Perusahaan Kecil. Penebar Swadava. Jakarta 